\title{
Ecological and Economical Violations as a Threat for Sustainable Development and National Environmental Safety (on Example of Kemerovo Region)
}

\author{
Roman Drapezo ${ }^{1, *}$, and Vitaly Shelestukov ${ }^{1,2}$ \\ ${ }^{1}$ Kemerovo State University, 650000, 6 Krasnaya st., Kemerovo, Russia \\ ${ }^{2}$ Plekhanov Russian University of Economics, Kemerovo branch, 650992, 39, Kuznetskiy prospect, \\ Kemerovo, Russia
}

\begin{abstract}
The article considers the analytical and statistical materials unfolding parameters of economic and ecological crime in Kemerovo Oblast. The close interrelation of quality indicators of the presented groups of crime is caused by the specifics of the coal-mining region. The illegal coal-mining developing in the territory of Kemerovo Oblast within the decades led to the irreversible ecological effects: pollution of rivers, air, soil, deforestation, etc. The administration of Kemerovo Oblast and the enterprises of the coal-mining industry paid attention to the problem not bringing desirable results. Formed in 2011 upon the request of the governor of Kemerovo Oblast the Prosecutor's Office on the supervision of respecting the rule of law in the coal-mining industry combines the efforts of Rostekhnadzor (the Federal Service for Ecological, Technological and Nuclear Supervision) and Rosprirodnadzor (the Federal Service for Nature Management Supervision) for the prevention of proliferation of crimes in this sphere. Kemerovo State University combines the efforts of scientific community, executive authorities, public organizations and not indifferent residents of Kemerovo Oblast to recognize and prevent economic and ecological offenses. Kemerovo State University has been regularly holding the ecological and tax forums on its basis in recent years. They let bring the factors causing threat of the national security of the region and country in general to the authorities and the public.
\end{abstract}

\section{Introduction}

The large-scale researches of the reserves of coal which are available in the south of Kuzbass were conducted in 1960s-1970s. The huge coal-beds with million strong deposits of "black gold" as well as the poor fields were charted. In general, the large open-casts were developed and others were out of touch because of their unprofitability. Up until the mid-1990s, the information on them was confidential but the information leakage happened while the transfer of many enterprises from one owner to another. At the same time, there

*Corresponding author: urinit@ @kemsu.ru 
were people owning the surveying cards, the mining equipment, having sales channels and ready to invest the considerable money in illegal coal mining. "Prospectors" provided everyone with the coal albeit not of top quality. The state damages from their activity were assessed at billions of rubles. That was a time when the Kuzbass law enforcement authorities began the active fight against this evil. The large-scale operation "Coal" yielded results at once. The illegal open-casts were being liquidated nearly every week, there were dozens of them. The legal proceedings were instituted one by one. The security agencies of Kemerovo Oblast and the neighboring regions took part in the decriminalization of a fuelenergy complex. Kemerovo Oblast is a leading coal region of the Russian Federation, possessing about $60 \%$ of this mineral here. There are 42 mines and 51 open-casts and also 54 coal-concentrating factories and facilities in the region. The Novokuznetsk area located in the south of Kuzbass is one of the largest centers of coal mining in the region. The 166.7 million tons of power brands of coal and 66.5 million tons of coking ones have been extracted in Kuzbass since the beginning of 2018. In comparison with the last year, the general gain made $5.4 \%$ or 12 million tons. Its illegal production causes the significant damage to the state. As a result, the budget receives less huge amounts of money. Besides, the illegal miners destroy and pollute road communications, undermine support of power lines, cause a loss to houses, land plots, country buildings, forest plantings and water reservoirs. Often ignoring the rules of conducting mining operations and safety measures, they endanger their lives.

\section{Materials and methods}

The empirical material for drawing up analytical and statistical reviews was taken from the legal portals. We present the qualitative description of the material in the Table 1:

Table 1. The qualitative description of the empirical material.

\begin{tabular}{|c|c|c|}
\hline Name of legal portal & URL & $\begin{array}{c}\text { Statistical material for } \\
\text { processing }\end{array}$ \\
\hline $\begin{array}{c}\text { 1. The website of } \\
\text { arbitration court of } \\
\text { Kemerovo Oblast }\end{array}$ & http://kemerovo.arbitr.ru & $\begin{array}{c}\text { Materials of arbitration cases } \\
\text { on economic and ecological } \\
\text { offenses since 2014 }\end{array}$ \\
\hline $\begin{array}{c}\text { 2. The portal of the } \\
\text { Russian Prosecutor's } \\
\text { Office }\end{array}$ & http://crimstate.ru & $\begin{array}{c}\text { Some statistical data on } \\
\text { economic and ecological } \\
\text { offenses }\end{array}$ \\
\hline $\begin{array}{c}\text { 3. The portal of the } \\
\text { legal-reference system } \\
\text { "ConsultantPlus" }\end{array}$ & http://consultant.ru & $\begin{array}{c}\text { Normative and help sources on } \\
\text { offenses in the field of } \\
\text { economic and ecological } \\
\text { security }\end{array}$ \\
\hline
\end{tabular}

The empirical material was processed through retrospective, comparative and statistical (graphic and correlation methods of the analysis) research methods. The graphs were made by means of Excel 2010 program, the coefficient of correlation was calculated with Statistica 6.5 program.

\section{Results and Discussion}

Today barbaric ways of illegal coal mining by "black diggers" were succeeded by more sophisticated "white-collar" way. In fact, a crime is just committed on paper. The coal extracted on the legalized area is not simply shown on balances of the enterprise, i.e. the coal is banally taken away from the taxation and the state suffers because of the direct 
losses as well as of the missed benefit. The subsurface use is a license process. The illegal miners of coal are out of this process. It means that the state does not receive not only the payments for the license but the taxes as well.

The Department of Economic Security and Anti-Corruption Enforcement at Ministry of Internal Affairs of Russia has stopped about 100 facts of illegal overburden operations in Kemerovo Oblast in last three years.

For example, the police officers stopped activity of two groups which were carrying out illegal overburden (related to the removal of the top rocks) operations in the areas of coal enterprises in Kiselyovsk city at the beginning of September in 2016. The places of illegal coal mining were spotted with the use of air drones. Five malefactors, using the excavator, the loader and the dump truck, smoothed out coal layer from the soil to organize the extraction of fuel on one of areas. However, the detectives found the place of overburden operations and caught "black diggers" who were the locals. Today the investigation has already acquired the experience of qualification of the facts of illegal coal mining as the embezzlement of property (Art. 158 of the Criminal Code of the Russian Federation) belonging to the state. The huge work on decriminalization of coal industry when practically all the regional bodies participated, was carried out for this purpose. In this direction of activity, the law enforcement bodies cooperate with Federal Security Service of Russia in Kemerovo Oblast, Kemerovo customs, Siberian division of Rostekhnadzor, Division of Rosprirodnadzor, Kemerovo Inter-district Prosecutor's Office on supervision of law enforcement in coal-mining branch and others [1].

The "Black diggers" cause not only big economic but also image damage to the region since the illegally extracted coal of poor quality is transported to other regions of the country. As a result, the bad quality of fuel affects the reputation of Kemerovo Oblast as the supplier of coal production.

The forward work of the Kuzbass police led to the fact that the tactics of "black diggers" has recently altered its nature into short-term "attacks", i.e. when coal is mainly extracted at night within 2-3 days then malefactors change the place of production.

The staff of internal affairs agencies of Kemerovo Oblast has stopped more than 20 facts of illegal coal mining in 2018. 6 criminal cases were brought against the organizers of such activity: five ones are on the essential elements of offense, the Criminal Code of the Russian Federation ("theft") provided by Art. 158, and one is upon illegal business (Art. 171 of the Criminal Code of the Russian Federation).

One of the largest arrests was carried out in Kiselyovsk city where the officers of the Department of Economic Security and Anti-Corruption Enforcement at Ministry of Internal Affairs of Russia in Kemerovo Oblast stopped the activity of an organized group of persons illegally extracting coal. According to the preliminary estimates, as a result of criminal acts the volume of the coal extracted from a subsoil of unallotted fund of the Russian Federation was 4,752 tons for the sum more than 8 million rubles. The organizers will be brought to trial for illegal business activity.

Of course, the illegal production is not the only type of crimes in coal industry, the Kuzbass police is fighting with. The crimes are also committed at the legal enterprises where workers are mostly often involved in them at the same time.

30 criminal cases on crimes in coal industry have been brought upon various corpus delicti so far this year, 25 of them are on crimes of economic orientation. For example, 11 criminal cases were brought on the facts of corruption crimes. The officers of the Department of Economic Security and Anti-Corruption Enforcement at Ministry of Internal Affairs of Russia documented 6 facts of bribery (Art. 291 of the Criminal Code of the Russian Federation) to the inspector of Rostekhnadzor from the heads of the coal enterprises. To ask the inspector to have his "eyes closed" to the existing violations, one of the enterprises sent several trucks of gravel to the inspector's residence, and another sent 4 
tons of metalware. The official condemned according to Art. 290 of the Criminal Code of the Russian Federation ("taking bribe") is obliged to pay 800 thousand rubles of a penalty. The heads of mines also became persons involved in criminal cases on bribery.

There are also ecological crimes along with the economic ones in the coal-mining industry of Kuzbass. The ecological situation in the regions, especially in industrially developed ones, is a "time-bomb". V.V. Putin, the Russian President, has fairly noted in his message to Federal Assembly "It is difficultly to speak about long and healthy life if millions of people are still drinking water which does not meet standards, if black snow is falling down in Krasnoyarsk, and the inhabitants of the large industrial centers have not seen the sun for weeks because of a smog, as in Cherepovets, Nizhny Tagil, Chelyabinsk, Novokuznetsk and some other cities" [2].

According to the observations of 2017, the level of atmospheric air pollution was estimated as high one in Kemerovo and Prokopyevsk; the very high is in Novokuznetsk. The very high pollution level in Novokuznetsk and high level in Kemerovo and Prokopyevsk are caused by the concentration of benzapyrene. The pollution level has increased in Prokopyevsk since last year and has not changed in Kemerovo and Novokuznetsk [3].

Unfortunately, for 15 last years, the ecological situation of the region has not improved despite the undertaken efforts. Kemerovo Oblast was included into the list of the eight "dirtiest" regions of Russia on an emissions level and dumpings of polluting substances into the environment in 2002. The total emission of polluting substances in the atmosphere made more than 1.5 million tons p.a., and dumping of polluting substances with waste waters made more than 0.5 million tons p.a. It was due to the fact of the location of more than 1,500 enterprises in its territory including: 30 enterprises of ferrous and nonferrous metallurgy; 127 enterprises of coal mining and coal treatment; 19 heat supply facilities; 14 enterprises of chemistry; 88 enterprises of mechanical engineering and metal working; 194 enterprises of building industry; 300 enterprises of the railway, motor transport and road maintenance [4-6].

The materials of public prosecutor's inspections demonstrate that the violations in the sphere of the nature protection legislation have numerous characters. In most cases, the violator of the legislation takes efforts for eliminating violations only under the pressure of bodies of prosecutor's office. It is mostly caused by lack of necessary financial means, legal illiteracy of the heads and sometimes it is the unwillingness to observe the provision of a law due to achieve the momentary goals without realizing heaviness and long-term harm done to the environment. In this regard, the strengthening of state supervision of provision of a law in the field of environmental control combined with the preventive activities directed to the commission of offenses as well as the information work will promote the compliance with the law and reduction of number of offenses in the field of environmental control (ch. 26 Criminal Code of the Russian Federation) [7].

Kemerovo Oblast is one of the most developed industrial regions of Russia and one of the most ecologically adverse at the same time.

In November 2018, the first criminal case in Kuzbass on essential elements of offense provided by Art. 251 of the Criminal Code of the Russian Federation "Air pollution" was brought. The citizens of Kemerovo complained to the law enforcement agencies about a specific smell in the air. The inspection was initiated. It revealed the maximum allowable concentrations of such pollutants as ammonia, nitrogen dioxide, soot, hydrogen chloride and carbon oxide. The level of atmospheric air pollution in the regional center was estimated as high in 2017 that has a negative impact on the population's health. A criminal case was brought upon results of the inspection by the investigator of the Ministry of Internal Affairs of Russia in Kemerovo Oblast. The similar criminal case was brought in Novokuznetsk as well. The law enforcement agencies have to find out the reason of 
pollution and bring the perpetrators to justice. Three criminal cases on the air pollution facts have been totally brought in Kuzbass for several months in 2019.

We show the types and structures of offenses in the sphere of economic and ecological security provided by the relevant standards of the Criminal Code of the Russian Federation and Code of the Russian Federation on Administrative Offences, taking place in Kemerovo Oblast in the table 2 .

Table 2. Types and structures of offenses in the field of economic and ecological security taking place in Kemerovo Oblast

\begin{tabular}{|c|c|c|}
\hline Types of offenses & \multicolumn{2}{|c|}{ Structures of offenses } \\
\cline { 2 - 3 } & $\begin{array}{c}\text { provided by the Criminal } \\
\text { Code of the Russian } \\
\text { Federation }\end{array}$ & $\begin{array}{c}\text { provided by the Code of the } \\
\text { Russian Federation on } \\
\text { Administrative Offences }\end{array}$ \\
\hline Economic offenses & $\begin{array}{c}\text { Art. 158, 171, 290, 291 of the } \\
\text { Criminal Code of the Russian } \\
\text { Federation }\end{array}$ & $\begin{array}{c}\text { chapters 14 and 15 of the Code } \\
\text { of the Russian Federation on } \\
\text { Administrative Offences (about } \\
8 \text { corpus delicti) }\end{array}$ \\
\hline Ecological offenses & $\begin{array}{c}\text { Art. 246-262 of the Criminal } \\
\text { Code of the Russian } \\
\text { Federation }\end{array}$ & $\begin{array}{c}\text { chapter 8 of the Code of the } \\
\text { Russian Federation on } \\
\text { Administrative Offences (53 } \\
\text { corpus delicti) }\end{array}$ \\
\hline
\end{tabular}

It is noticeable that the greatest number of structures of offenses is stipulated by the legislation in the field of ecological security.

Let us consider the jurisprudence of arbitration court of Kemerovo Oblast of cases on economic and ecological offenses during the period from 2014 to 2018.

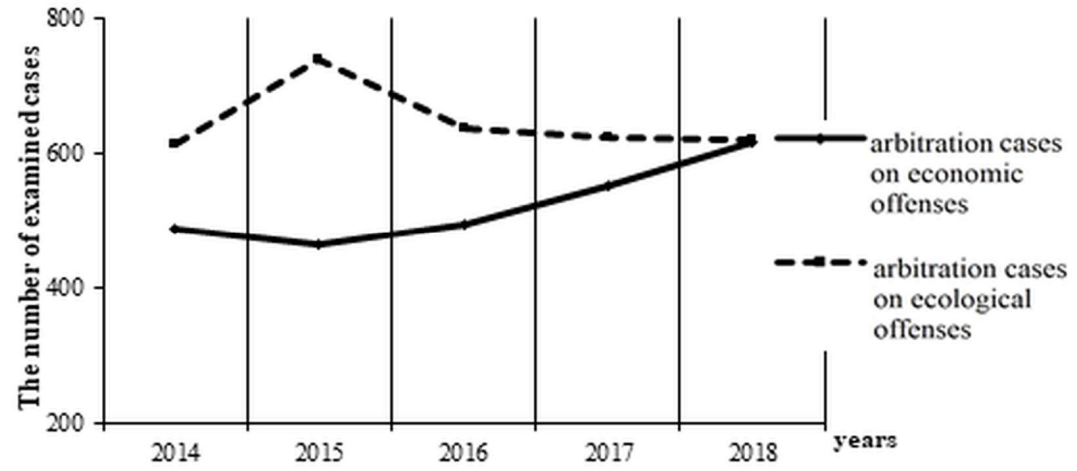

Fig. 1. The dynamics of consideration of cases on economic and ecological offenses by arbitration court of Kemerovo Oblast during the period from 2014 to 2018.

According to the correlation of coefficient value $(r=-0.92$ at the level of the forecast of $\mathrm{p}<0.05$ ) which shows us the associativity degree, with an accuracy of forecast of $92 \%$, we can claim that two social and legal phenomena studied by us in the territory of Kemerovo Oblast, such as economic and ecological offenses, are interconnected, i.e. have interdependent character. The negative sign of coefficient of correlation demonstrates that the growth of offenses in the field of economic security will lead to falling number of the committed offenses in the ecological sphere and vice versa. Knowing this regularity, law enforcement agencies will be able to predict the nature of changes of economic and ecological offenses and stop these types of offenses opportunely.

The state programs of Kemerovo Oblast "Ecology, subsurface use and rational water use" for 2017-2020 approved by the resolution of Board of Administration of Kemerovo 
Oblast of 16.09.2016 No. 362 [8] and the "Defense, protection, reproduction, the use of forests and objects of fauna of Kuzbass" for 2017-2020 approved by the resolution of Board of Administration of Kemerovo Oblast of 08.11.2016 No. 430 [9, 3] were implemented in 2017.

The ecological forum representing the platform for forming the expert scope on the discussion of problems of environmental control and environmental management, state policy in the field of ecology, a legal treatment of changes of the legislation in the field of environmental control and environmental management took place in Kemerovo State University (KemSU) on November $16^{\text {th }}, 2018$. Alexander Prosekov, the rector of KemSU, made the forum report "Anthropocene and its ecological effects" in which he placed emphasis on the main global ecological effects from the economic activity of a person: reduction of populations of wildings, growth of ozone holes, climate changes, melting of glaciers, increasing garbage, etc. Rector noted in his report that the higher education institution conducts the works of ecological orientation. So, for example, PAH center (Pilotless Air Hub) is founded at KemSU for the inspection of forests by means of the drones equipped with the photo and video gear.

The report by Sergey Vysotsky, the head of the department of natural resources and ecology of Kemerovo Oblast, was devoted to carrying out "Year of Ecology" in Kemerovo Oblast. He noted in his message the priority directions of the plan of "Year of Ecology" and the main nature protection actions which took place in the region in 2017. It was noted that the record on the start of treatment facilities of mine waters at the enterprises of coal mining is set up in Kuzbass this year. Today 7 treatment facilities have been already started and the start of treatment facilities at one more enterprise is planned until the end of the year. It was also noted that not all enterprises follow the requirements of the nature protection legislation. Thus, it is necessary to find ways of legal impact on their heads. The regional state inspectors have revealed more than 400 ecological violations through this year, the perpetrators are brought to the administrative responsibility.

The women's forum "Role of the Woman in Development of Industrial Regions" with the expert session "Ecological Situation in Russian Regions" took place in Novokuznetsk on March $1^{\text {st }}$ and $2^{\text {nd }}, 2019$. Some questions were considered within this session: implementation of global initiatives in the field of ecology in regions; perspectives of implementation of projects of ecological orientation in utility, coal-mining and transport spheres of the region; green economy and use of the best available technologies in the industry.

During his working visits of March $12^{\text {th }}, 2019$, Sergey Tsivilev, the governor of the region, suggests to reform the approaches to the development of coal branch in Kuzbass. In this, the major tasks for the governor are the safety, quitting transportation of coal across public roads and bringing in an ecological standard. In addition, the "Clean Kuzbass Pure Coal" program offered by the governor sets its purpose to fight against "black diggers" through the coordinated work with reliable, socially responsible companies who will honor their commitments undertaken to the citizens.

\section{Conclusion}

We may conclude upon the above that:

1. The economic and ecological crime in Kemerovo Oblast has an interdependent character $(r=-0.92$ if $p<0.05)$, i.e. the illegal coal mining by "black diggers" results in the destruction of integrity of land and forests, pollution of water and air objects on the one hand, and non-payment of taxes and contributions to the relevant funds on the other. The law enforcement agencies, knowing this regularity, have got the instrument of forecasting and opportune response to any changes of the studied types of offenses. 
2. The Nature Protection Prosecutor's Office and Prosecutor's Office on supervision of compliance with the law in the coal-mining industry of Kemerovo Oblast ought to take effective measures to strengthening the prosecutor's supervision of compliance with the law in the sphere of industrial safety and labor protection at the enterprises of coal-mining industry operating hazardous production facilities. The regional prosecutors have to be focused on the high-quality prosecutor's supervision of strict compliance with the requirement of the current legislation by the officials of local bodies of Rostekhnadzor and Rosprirodnadzor when performing the function in defined scope of activities as well as to pay special attention to the completeness and efficiency of the measures for control and supervision taken by the mentioned departments [10]

3. The intermediate results of implementation of the federal program "The Formation of Comfortable Urban Environment" (i), identification of problems of controlling the quality of environmental and nature management (ii), determination of the priority directions of environmental policy of Kemerovo Oblast (iii), increase in level and quality of lawmaking, law enforcement, control and supervising, educational and scientific activity (iv), strengthening of professional bonds (v) should be entered into the system of monitoring of economic and ecological security of the region.

\section{References}

1. V. Shelestukov, V. Erin, G. Pavlov, E3S Web Conf., 41, 02029 (2018)

2. The message of Russian President to the Federal Assembly (TASS, Moscow, 2018)

3. The report of Department of natural resources and ecology of Kemerovo Oblast on the state and environmental protection of Kemerovo Oblast in 2017 (AKO, Kemerovo, 2017)

4. E.A. Mamontova, A.A. Mamontov, E.N. Tarasova, Rus. J. Gen. Ch., 86:13, 29872996 (2016)

5. S. Bortnikova, V. Olenchenko, O. Gaskova, N. Yurkevich, N. Abrosimova, E. Shevko, A. Edelev, T. Korneeva, I. Provornaya, L. Eder, App. Geochem., 93, 145-157 (2018)

6. The sanitary and epidemiologic situation in Kemerovo Oblast in 2011: the state report (AKO, Kemerovo, 2012)

7. M. Agienko, A. Naumov, I. Gaag, Yu. Volgin, E3S Web Conf., 41, 04046 (2018)

8. The resolution of Board of Administration of Kemerovo Oblast of September $16^{\text {th }}$, 2016 No. 362 "The approval of the state program of Kemerovo Oblast "Ecology, subsurface use and rational water use" for 2017 - 2019" (AKO, Kemerovo, 2016)

9. The resolution of Board of Administration of Kemerovo Oblast of November $8^{\text {th }}, 2016$ No. 430 "The approval of the state program of Kemerovo Oblast "Defense, protection, reproduction, the use of forests and objects of fauna of Kuzbass" (AKO, Kemerovo, 2019)

10. M. Agienko, Yu. Volgin, E. Moroz, T. Olofinskaya, E3S Web Conf., 41, 02030 (2018) 